\title{
The impacts of human resource management practices on employees' motivation and loyalty
}

\author{
Mai Ngoc Khuong ${ }^{a^{*}}$, Tran Phuong Mai ${ }^{a}$ and Nguyen Thi Minh Phuonga
}

${ }^{a}$ International University - Vietnam National University, Ho Chi Minh City, Vietnam

\begin{tabular}{l}
\hline C H R O N I C L E \\
\hline Article history: \\
Received: February 16, 2020 \\
Received in revised format: \\
March 22 2020 \\
Accepted: March 22, 2020 \\
Available online: \\
March 22, 2020 \\
\hline Keywords: \\
Human resource management \\
practices \\
Employee loyalty \\
Motivation \\
Team spirit \\
Career development \\
Hospitality Sector \\
Vietnam
\end{tabular}

\section{A B S T R A C T}

\begin{abstract}
The research was conducted in order to identify the relationships between human resource practices, employee motivation and employee loyalty. Quantitative research method was applied with questionnaires directly delivered to 595 employees in hospitality sector in Ho Chi Minh city, Vietnam. Statistics techniques including exploratory factor analysis, reliability analysis, multiple regression and mediation analysis were used. The empirical results showed that variables of team spirit, career development, compensation, relationship with manager and working environment directly affected employee motivation and consequently, they provided indirect effects on loyalty through the mediation of employee motivation. In addition, employee loyalty was also directly affected by career development, working environment and employee motivation. It is suggested that hospitality sector should develop attractive compensation and benefit policies, comfortable workplace environment, coherent teamwork culture as well as straightforward career training and development plan for achieving higher level of employee loyalty.
\end{abstract}

C 2020 by the authors; licensee Growing Science, Canada

\section{Introduction}

It cannot be deniable that hospitality industry in Vietnam is experiencing a vast development in recent years. In the first 9 months of 2019, Vietnam welcomed nearly 13.5 million international tourists, which increased up to around $10.8 \%$ compared to 2015 (CBRE, 2019). Along with the growth of this industry, there are $4424-5$ star hotels under operation, which illustrates $44 \%$ rise in number of $4-5$ star hotels in Vietnam during 4 years from 2015 to 2019. Apart from high - class accommodation, other Vietnamese start - up organizations including Luxstay, MyTour, Vntrip and Ivivu were established to support for the development of tourism. Moreover, foreigner partners such as Redoorz and Oyo have joined Vietnamese tourism market to provide a wide range of accommodation for international and domestic tourists. Regarding economic contribution, in 2018, travel and tourism GDP was nearly US\$27 billion, constituting 8\% in Vietnam's GDP (VNS, 2019) and was predicted to grow up to $9.8 \%$ in the next decade according to the World Travel and Tourism Council (WTTC). It is able to conclude from the above evidence that tourism and hospitality industry in Vietnam is considered as a determinant role in the whole economy development. As a labor - intensive industry, hospitality organizations always search for excellent human resource management tools to improve their service performance as well as employee performance, employee motivation and employee loyalty. Employee loyalty was defined as attachment feeling of employees to their organization (Tomic et al., 2018) or the favorable working environment that employees want to commit the organization with a high level of service quality (Yee et al., 2010). These studies also pointed out the importance of employee loyalty in determining firm profitability through the positive impact on service quality. In addition to service quality, employee loyalty was discovered as a significant role influencing employees' engagement and work outcomes (Ibrahim \& Al Falasi, 2014). The more loyalty of employees to organization, the higher employee engagement, which leads to better teamwork, performance and lower turnover rate.

* Corresponding author.

E-mail address: mnkhuong@hcmiu.edu.vn (M. N. Khuong)

(C) 2020 by the authors; licensee Growing Science, Canada doi: $10.5267 /$ j.msl.2020.3.025 
Another determinant factor beside employee loyalty is employee motivation. It was proved in the research of (Al Araimi, 2002) that compensation and relationship with colleagues positively were related to employee motivation. Thus, employee motivation had direct positive relationships with employee commitment, sense of flow (Watson et al., 2018) and employee creativity (Hur et al., 2016). Not only a number of studies found out the meaningful impact of employee motivation but many motivation theories have also been developing throughout the years to increase employee motivation practically. One of the most well - known theories is Maslow hierarchy of needs in which managers could identify the need levels of their employees to utilize for their motivation. Despite the variety of theories and studies about employee motivation and employee loyalty around the world, there are few studies about these factors as well as human resource in hospitality in Vietnam. For instance, Bui and Sid (2019) identified the impact of human resource practices on employee engagement in banking industry or Pham(2019) clarified the influence of human resource on business performance in telecommunication industry. Therefore, this study is believed to be the first leading research about the human resource practices (team spirit, compensation, career development, relationship with manager, working environment) effect on employee motivation and employee loyalty in hospitality industry in Vietnam. Since then, it could be a theoretical platform for management levels to implement appropriate and practical strategies to enhance employee motivation and reduce turnover rate in order to improve service quality. Based on the research of Chang et al. (2010) and Turkyilmaz et al. (2011), the study developed a model of independent variables including team spirit, compensation, career development, relationship with manager and working environment in relationship with mediating variable - employee motivation and dependent variable - employee loyalty.

\section{Literature Review}

\subsection{Employee loyalty}

It was mentioned in the research of (Ineson \& Berechet, 2011) that employee loyalty was affected by a number of factors including salary, benefits, interpersonal characteristics, personal incentives, hierarchical position, etc. Moreover, they also identified a positive linkage between employee loyalty and job satisfaction. In addition to job satisfaction, Yee et al. (2010) indicated a positive association between employee loyalty and service quality, which resulted in higher customer satisfaction. Under other conditions, Yao et al. (2019) considered behavioral loyalty of employees as antecedents and consequences of hotel employee organizational commitment. They also believed that employee loyalty, beside economic compensation, is significantly influenced by other facets such as social and affective factors.

In detail, there was a direct remarkable relationship between career development and employee loyalty in lodging industry (Costen \& Salazar, 2011). In regard to indirect correlation, trust in colleagues and in management (Matzler \& Renzl, 2006), employee compensation, teamwork, empowerment (Chang et al., 2010) had significant impact on employee job satisfaction which led to positive influence on employee loyalty (Turkyilmaz et al., 2011).

\subsection{Employee motivation}

Employee motivation over the years has been studied and developed with a variety of motivational theories including Maslow's Hierarchy of Needs, Herzberg's Two Factor Theory, etc. (Dermody et al., 2004). It was also pointed out about the significant effect of co - workers and work environment on employee motivation. Wang (2016) also made contribution in the research of (Dermody et al., 2004) that high quality LMX in hotels could increase employees' task motivation. Therefore, it was recommended that organization should take more notice of positive influences from leaders to member to strengthen motivation. On the academic aspect, McClelland developed theories of needs including three motivations: need for affiliation, need for power and need for achievement (McClelland, 1985). In detail, Liu et al. (2016) identified that a good and stable relationship between managers and coworkers could encourage employees and attract a high need for affiliation, the direct influence of employee on customer satisfaction would fulfill employees' need for power and customers' complaints solving could attain a need for achievement. Regarding the consequence of employee motivation, it was estimated that motivational factors could have positive association with employees' loyalty (Chen \& Lin, 2013; Curtis et al., 2009). Meanwhile, Mak and Sockel (2001) defined that motivation had an indirect correlation with loyalty through retention. To be more specific, an increase in motivation results in a growth in retention and a high level of retention leads to a high level of loyalty.

\subsection{The factors affect to employee loyalty and employee motivation}

\section{Team spirit}

Team was defined as a group comprising of interdependent employee working together to achieve common goal (Parker \& Wall, 1998). On the other hand, Mudambi et al. (2007) described teamwork as a cooperative networking and communication within an organization or among different properties. It was undeniable that there were many advantages to implement teamwork over individuals including higher satisfaction and commitment, higher quality of service and product as well as increasing productivity (Maxwell, 2008). 
As a determinant factor in improving quality service, an effective teamwork that employees were provided autonomy strengthened employee motivation and resulted in enhancing employee performance and excellent service (Meterko et al., 2004; Gallie et al., 2012). Likewise, it was defined that teamwork rose organization effectiveness (Ramsay et al., 2000) and employee job satisfaction (Turkyilmaz et al., 2011) by increasing employee motivation. Apart from the direct influence on employee motivation, teamwork was considered to have indirect impact on employee loyalty through the mediating effect of employee satisfaction (Chang et al., 2010; Arsić et al., 2012). In other words, teamwork was positively associated with employee satisfaction and employee satisfaction is clarified to have positive relationship with employee loyalty (Jun et al., 2006).

\section{Compensation}

It is a human resource management tool to retain people as employers understand that employees need to guarantee their financial statement based on offered compensation and benefits (Chiu et al., 2002). Likewise, Li and Roloff (2008) identified the coherent relationship between compensation systems and organizational culture, which was considered as a mean to retain and motivate employees. Regarding employee motivation, compensation has different aspects influencing on employee motivation in different manners. According to Litman et al. (2014), compensation related to monetary rewards was the most effective motivation compared to other factors. The evidence was also supported by (Cooke, 1999) that money - equivalents are the key motivators in sale management. In addition to monetary - related compensation, the design and implementation of compensation also had impact on employee motivation and even other practical results (Gupta \& Shaw, 2014). On the other hand, the relationship between compensation and employee loyalty was rarely defined clearly. Chang et al. (2010) and Jun et al. (2006) pointed out that compensation belong to TQM (Total Quality Management) practices which had indirect impact on employee loyalty through the mediation of employee satisfaction. In addition to the indirect effect, Carraher (2001) and Milman (2003) believed that low compensation also led to the lack of employee loyalty.

\section{Career development}

Career development assisted employees in identifying their talents so that they were able to optimize their potential abilities for organization (Conger, 2002). Therefore, to implement an effective career development program, employers should take notice of individuals and organizational factors affecting job performance as career development was a mediating factor in the relationship of job satisfaction, organizational commitment with job performance (Lee \& Lee, 2018). Beside the mediating effect, London (1993) identified the direct positive relationship of support for career development on employee career motivation. In detail, subordinates' career motivation would be higher when they perceive more support and empowerment from their superiors. Moreover, career development acted as an important role in reducing intention to leave (Chew \& Chan, 2008; Kroon \& Freese, 2013). In addition to the direct effect on intention to stay, career development was proved to be the influenced factor in the linear relationship between job satisfaction and employee loyalty (Turkyilmaz et al., 2011).

\section{Relationship with manager}

Leader-member exchange theory (LMX) was defined as the structure for the relationship between the leader and the follower, which was considered as a necessary component determining the organization engagement (Laschinger et al., 2007). According to (Baird \& Kram, 1983), the relationship between managers and subordinates comprised of two people, each of whom would have different needs and requirements in the corresponding conditions. An effective leader - member relationship when it was responsive to individuals' concerns. It was estimated that improving employee - supervisor relationship was an effective tool to enhance work motivation for employees (Klein \& Kim, 1998). LMX is also considered as a motivation factors for employee to increase their performance (Sekiguchi et al., 2008; Selvarajan et al., 2018; Wang, 2016). Therefore, management levels were recommended to provide a comfortable environment and resource for employees to achieve high - quality LMX. It was rarely to find any research about the correlation between leader/follower relationship and employee loyalty. However, recently, Book et al. (2019) has clarified the indirect relationship of LMX on employee loyalty through employee engagement.

\section{Working environment \& condition}

Work environment was believed to affect positively or negatively to employees to achieve their performance (Wright \& Davis, 2003). For instance, in the research of Leather et al. (1998), they clarified the positive effect of light penetration on job satisfaction, well-being and negatively affected on turnover intention or according to (Singh et al., 2010), they identified that the more green the building was, the more productive and happier the workers got. Work environment was also considered as a creativity and innovation motivation factor in business (Amabile, 1997). Supporting this claim, Rasheed et al. (2016) showed that working environment was a significant variable affecting employees' motivation. Moreover, following Maslow's need hierarchy, at the second level, it indicated the need of employees for a secure and stable working environment. As mentioned above, working condition was proved to be one of the most key factors impact on employee satisfaction. Consequently, through employee satisfaction, (Turkyilmaz et al., 2011), they found out the positive linear relationship between employee satisfaction and employee loyalty, which referred to the indirect correlation between working environment and employee loyalty. 


\subsection{Research hypothesis}

In order to obtain all objectives and further analysis, this study hypothesizes that:

H1: Factors of team spirit, compensation, career development, relationship with manager, working environment and condition, fringe benefits directly affect employee loyalty.

H2: Factors of team spirit, compensation, career development, relationship with manager, working environment and condition, fringe benefits directly affect employee motivation.

H3: Employee motivation directly affects employee loyalty.

H4: Factors of team spirit, compensation, career development, relationship with manager, working environment and condition, fringe benefits indirectly affect employee loyalty through the mediation of employee motivation.

\section{Research methodology}

The research applied quantitative approach to examine the relationship among independent, mediating and dependent variables. The data survey used 5 Likert scales to establish the accurate result and was collected from 595 employees (hotel and restaurant front line staff, low, middle, and high level managers) working in hospitality industry in Ho Chi Minh City. SPSS version 20 was applied in this research to perform statistics techniques including frequencies, means, standard deviation, EFA (exploratory factor analysis), Cronbach's alpha, multiple regression and mediation analysis (F.Hayes, 2018). The measurement scale of variables is described in Table 1 as follows,

Table 1

Measurement scales of variables

\begin{tabular}{|c|c|c|c|}
\hline & Variable & \# of items & Reference \\
\hline \multirow{5}{*}{ Independent variables } & Team spirit & 8 & (SHRM, 2015) \\
\hline & Compensation & 11 & (SHRM, 2014) \\
\hline & Career development & 7 & (SHRM, 2015) \\
\hline & Relationship with managers & 4 & (SHRM, 2015) \\
\hline & Working environment and condition & 22 & (SHRM, 2015) \\
\hline Mediating variables & Employee motivation & 10 & $\begin{array}{c}\text { (SHRM, 2015) } \\
\text { (Guterresa, Armanu, \& Rofiaty, 2019) }\end{array}$ \\
\hline Dependent variables & Employee loyalty & 5 & $\begin{array}{l}\text { (Bettencourt, Gwinner, \& Meuter, 2001) } \\
\text { (Gandhi, Sachdeva, \& Gupta, 2018) }\end{array}$ \\
\hline
\end{tabular}

Factor analysis

Reliability analysis for variables was applied using Cronbach's Alpha coefficient. The reliability level of Cronbach's Alpha was identified by (Hair et al., 2003). In detail, the range which is lower than 0.6 is referred as low reliability, 0.6 to 0.7 is moderate reliable, 0.7 to 0.8 is good reliability level, 0.9 to 0.95 is excellent reliable and greater than 0.95 is too high (the items should be verified to make sure they are not redundant). The reliability test of all variables (after eliminated low reliable items of each factor) is represented in Table 2.

Table 2

Reliability and validity of measurement scale

\begin{tabular}{lccc} 
Independent Variables & $\begin{array}{c}\text { Number of } \\
\text { items }\end{array}$ & Cronbach's alpha & $\begin{array}{c}\text { Total Variance Ex- } \\
\text { plained }\end{array}$ \\
\hline Team spirit (TEASPI) & $8^{*}$ & 0.870 & \\
Compensation (COMPEN) & $5^{*}$ & 0.844 & \\
Career development (CARDE) & $5^{*}$ & 0.805 & $59.091 \%{ }^{* *}$ \\
Relationship with manager (REWIMA) & $3^{*}$ & 0.756 & \\
Working environment (WOEN) & $4^{*}$ & 0.724 & \\
Working condition (WOCO) & $4^{*}$ & 0.752 & $50.772^{* *}$ \\
Fringe benefit (FRIBE) & $4^{*}$ & 0.715 & \\
\hline Employee motivation (EMOTI) & $10^{*}$ & 0.875 & \\
Employee loyalty (EMLOY) & $5^{*}$ & 0.806 & \\
\hline
\end{tabular}

*All items have factor loadings $>0.5$

$* *$ KMO indexes $>0.9$ and sig. $=.000<0.05$ 
For the eigenvalues greater than 1, there were 7 components extracted including team spirit, compensation, career development, relationship with manager, working environment, working condition and fringe benefit. Seven independent variables were appropriate for factor analysis as the KMO index $(0.940>0.5)$ and the Bartlett's test of sphericity $(\mathrm{p}=.000<0.05)$ were all acceptable. These 7 variables explained 59.091\% for the total variance. Furthermore, with the high value of Cronbach's Alpha of independent components, they experienced the high reliability for analysis. Likewise, mediating variable (employee motivation) and dependent variable (employee loyalty) were estimated to be suitable for further research as the KMO index $(0.915>0.5)$ and the Bartlett's test of sphericity $(\mathrm{p}=.000<0.05)$. These two variables were extracted component with the total variance explained at $50.772 \%$. In regard to reliability value, with the high Cronbach's Alpha $(>0.8)$, it indicated the good reliability to conduct further research.

\section{Data Analysis \& Findings}

\subsection{Demographic of respondents}

Profile of respondents is summarized in Table 3 as follows,

Table 3

Demographic statistics of respondents

\begin{tabular}{|c|c|c|c|}
\hline & & Frequency & Valid Percent \\
\hline \multirow{4}{*}{ Job position } & - Hotel and Restaurant front line staff & 286 & 48.1 \\
\hline & - Low level managers & 215 & 36.1 \\
\hline & - Middle level and high ranked managers & 94 & 15.8 \\
\hline & Total & 595 & 100.0 \\
\hline \multirow{3}{*}{ Gender } & - Male & 286 & 48.1 \\
\hline & - Female & 309 & 51.9 \\
\hline & Total & 595 & 100.0 \\
\hline \multirow{3}{*}{ Marital status } & - Single & 412 & 69.2 \\
\hline & - Married & 183 & 30.8 \\
\hline & Total & 595 & 100.0 \\
\hline \multirow{6}{*}{ Working period } & $-<1$ year & 102 & 17.1 \\
\hline & $-1-3$ years & 239 & 40.2 \\
\hline & $-3-6$ years & 173 & 29.1 \\
\hline & $-6-10$ years & 61 & 10.3 \\
\hline & - Over 10 years & 20 & 3.4 \\
\hline & Total & 595 & 100.0 \\
\hline \multirow{7}{*}{ Age } & $-<18$ & 8 & 1.3 \\
\hline & $-18-22$ & 149 & 25.0 \\
\hline & $-23-30$ & 325 & 54.6 \\
\hline & $-31-45$ & 97 & 16.3 \\
\hline & $-46-65$ & 14 & 2.4 \\
\hline & - Over 65 & 2 & 0.3 \\
\hline & Total & 595 & 100.0 \\
\hline \multirow{6}{*}{ Education } & - High school & 31 & 5.2 \\
\hline & - Vocational school & 81 & 13.6 \\
\hline & - College & 241 & 40.5 \\
\hline & - University & 216 & 36.3 \\
\hline & - Post university & 26 & 4.4 \\
\hline & Total & 595 & 100.0 \\
\hline
\end{tabular}

Most of the respondents were employees and low - level managers, which accounted for $84.2 \%$; whereas, the remaining were middle and high - ranked managers. Regarding gender, there was a balance percentage between male and female respondents (48.1\% and 51.9\%, respectively). A large proportion of them belongs to young generation from $18-30$ years of age (79.6\%); meanwhile, employees from $31-45$ and from $46-65$ constituted only $16.3 \%$ and $2.4 \%$, in order. As a result, the percentage of single occupied up to two - thirds and the marriage percentage made up to only $30.8 \%$. As the high turnover rate characteristic in hospitality industry, from the data survey, up to $40.2 \%$ employees worked from $1-3$ years, $29.1 \%$ from $4-6$ years, $10.3 \%$ from $7-10$ years and just 3.4\% over 10 years. Around 40\% respondents graduated from college and $36.3 \%$ from university. Following is vocational school with $13.6 \%$, high school with $5.2 \%$ and post university with $4.4 \%$. In conclusion, as the study focused on employee level; therefore, most of them were young, single and have few years of experience.

\subsection{Data findings \& result}

Table 4 explains all the correlations (all significant at $\mathrm{p}<.05$ ) among independent variables, mediating variable and dependent variable. The strongest positive relationship is between team spirit and employee motivation $(\mathrm{r}=.710, \mathrm{p}<.05)$, which means that the better team spirit, the higher employee motivation. 
Table 4

Summary of All Variables with Reliability Coefficients

\begin{tabular}{|c|c|c|c|c|c|c|c|c|c|}
\hline & EMLOY & 1 & 2 & 3 & 4 & 5 & 6 & 7 & 8 \\
\hline EMLOY & 1.000 & & & & & & & & \\
\hline TEASPI & .543 & 1.000 & & & & & & & \\
\hline COMPEN & .482 & .593 & 1.000 & & & & & & \\
\hline CARDE & .568 & .611 & .612 & 1.000 & & & & & \\
\hline REWIMA & .480 & .570 & .538 & .519 & 1.000 & & & & \\
\hline WOEN & .540 & .519 & .433 & .491 & .485 & 1.000 & & & \\
\hline WOCO & .507 & .667 & .574 & .562 & .596 & .520 & 1.000 & & \\
\hline FRIBE & .487 & .598 & .564 & .559 & .540 & .453 & .549 & 1.000 & \\
\hline EMOTI & .604 & .710 & .688 & .641 & .606 & .608 & .693 & .647 & 1.000 \\
\hline Mean & 3.76 & 3.60 & 3.47 & 3.60 & 3.60 & 3.81 & 3.62 & 3.58 & 3.65 \\
\hline$S D$ & .670 & .660 & .752 & .684 & .725 & .626 & .679 & .680 & .608 \\
\hline
\end{tabular}

\section{Direct effect of employee loyalty}

As Table 5 shows, there is no direct effect of team spirit, compensation, relationship with manager, working condition and fringe benefit on employee loyalty as $\mathrm{P}-$ value $>.05$. On the contrary, employee loyalty experienced a direct positive influence of employee motivation with $(\beta=.189, P=.001)$. Likewise, career development and working environment have direct positive association with employee loyalty with $(\beta=.217, P=.000$ and $\beta=.208, P=.000)$ respectively. These hypothesizes supported the previous researches of (Turkyilmaz et al., 2011; Chen \& Lin, 2013). $\mathrm{R}^{2}=.463$ pointed out that $46.3 \%$ of the variance in employee loyalty was explained by career development, working environment and employee motivation.

Table 5

Effect Coefficients between all variables and employee loyalty

\begin{tabular}{|c|c|c|c|c|}
\hline Hypothesis & $\beta$ & $\mathbf{T}$ - value & $P$ - value & Decision \\
\hline TEASPI $\rightarrow$ EMLOY & .087 & 1.797 & .073 & Rejected \\
\hline COMPEN $\rightarrow$ EMLOY & .005 & .116 & .908 & Rejected \\
\hline CARDE $\rightarrow$ EMLOY & .217 & 4.968 & .000 & Supported \\
\hline REWIMA $\rightarrow$ EMLOY & .059 & 1.408 & .160 & Rejected \\
\hline WOEN $\rightarrow$ EMLOY & .208 & 5.264 & .000 & Supported \\
\hline WOCO $\rightarrow$ EMLOY & .023 & .483 & .629 & Rejected \\
\hline FRIBE $\rightarrow$ EMLOY & .050 & 1.169 & .243 & Rejected \\
\hline EMOTI $\rightarrow$ EMLOY & .189 & 3.372 & .001 & Supported \\
\hline
\end{tabular}

Model summary: $\mathrm{R}^{2}=.463$

\section{Indirect effect of employee loyalty}

The result of multiple regression implied that employee motivation was directly influenced by all independent variables. In addition, employee motivation was directly associated with employee loyalty; therefore, all independent variables experienced indirect relationship with employee loyalty. In detail, as indicated in Table 6, team spirit, compensation, career development, working environment, working condition and fringe benefit significantly influence on employee motivation positively. The strongest impact on employee motivation is compensation $(\beta=.230, P=.000)$, following are team spirit $(\beta=.188, P=.000)$, working environment $(\beta=.182, P=.000)$, working condition $(\beta=.179, P=.000)$, fringe benefit $(\beta=.145, P=.000)$ and career development $(\beta=.084, P=.009)$. On the other hand, relationship with manager has a marginal positive effect on employee motivation with $(\beta=.058, P=.058)$. The positive correlations of these independent variables on employee motivation were consistent with the researches of London (1993), Klein and Kim (1998), Kasper et al. (2012) and Gupta and Shaw (2014). The $\mathrm{R}^{2}=.71$, shows the high appropriateness of the model and data and describes that $71 \%$ of the variance in employee motivation was explained by team spirit, compensation, career development, relationship with manager, working environment \& condition, fringe benefit.

Table 6

Effect Coefficients between Independent Variables and Employee Motivation

\begin{tabular}{|c|c|c|c|c|}
\hline Hypothesis & $\beta$ & T - value & $P$ - value & Decision \\
\hline TEASPI $\rightarrow$ EMOTI & .188 & 5.441 & .000 & Supported \\
\hline COMPEN $\rightarrow$ EMOTI & .230 & 7.264 & .000 & Supported \\
\hline CARDE $\rightarrow$ EMOTI & .084 & 2.636 & .009 & Supported \\
\hline REWIMA $\rightarrow$ EMOTI & .058 & 1.899 & .058 & Supported \\
\hline WOEN $\rightarrow$ EMOTI & .182 & 6.471 & .000 & Supported \\
\hline WOCO $\rightarrow$ EMOTI & .179 & 5.357 & .000 & Supported \\
\hline FRIBE $\rightarrow$ EMOTI & .145 & 4.708 & .000 & Supported \\
\hline
\end{tabular}


Table 7 used MEDIATE macro model for mediation analysis of (F.Hayes, 2018). The outputs provided the bootstrap confidence intervals at $90 \%$. If there is a ZERO between lower boundary (LL) and upper boundary (UL), there is no indirect effect. On the contrary, if ZERO does not exist in the range of LL and UL, the indirect effect is significant with $90 \%$ confidence. As a result, it was withdrawn from the Table 7 that all employee motivation fully mediated the positive impact of compensation, team spirit, relationship with manager, fringe benefit, working condition on employee loyalty $(\beta=.044, .036, .011, .028$, .034), respectively. On the other hand, career development and working environment experienced the partial meditation of employee motivation in the relationship with employee loyalty with $\beta=.016$ for the former and $\beta=.034$ for the latter. Moreover, the outcome of mediation analysis developed the theory about the indirect effect on employee loyalty from the previous studies - the indirect impact of career development and working environment (Turkyilmaz et al., 2011), team spirit and compensation (Chang et al., 2010), fringe benefit (Hsu \& Wang, 2008) on employee loyalty through employee satisfaction and the indirect effect of relationship with manager on employee loyalty through employee engagement (Book et al., 2019).

Table 7

Direct, indirect and total casual effects

\begin{tabular}{|c|c|c|c|c|c|}
\hline \multirow{2}{*}{ Variables } & \multicolumn{3}{|c|}{ Casual Effects } & \multirow{2}{*}{$\mathbf{L L}$} & \multirow{2}{*}{ UL } \\
\hline & Direct & Indirect & Total & & \\
\hline CARDE & .217 & .016 & .233 & .0045 & .0293 \\
\hline WOEN & .208 & .034 & .242 & .0177 & .0580 \\
\hline TEASPI & - & .036 & .036 & .0165 & .0583 \\
\hline COMPEN & - & .044 & .044 & .0187 & .0606 \\
\hline REWIMA & - & .011 & .011 & .0010 & .0214 \\
\hline WOCO & - & .034 & .034 & .0153 & .0541 \\
\hline FRIBE & - & .028 & .028 & .0121 & .0449 \\
\hline Total & .425 & .203 & .628 & & \\
\hline
\end{tabular}

Causal effect of employee loyalty

According to Table 7, working environment had the strongest impact on employee loyalty $(\beta=.242)$, following is career development $(\beta=.233)$, compensation $(\beta=.044)$, team spirit $(\beta=.036)$, working condition $(\beta=.034)$, fringe benefit $(\beta=$. $028)$ and the weakest effect is relationship with manager $(\beta=.011)$. In conclusion, the total effect of independent variables on employee loyalty is .628.

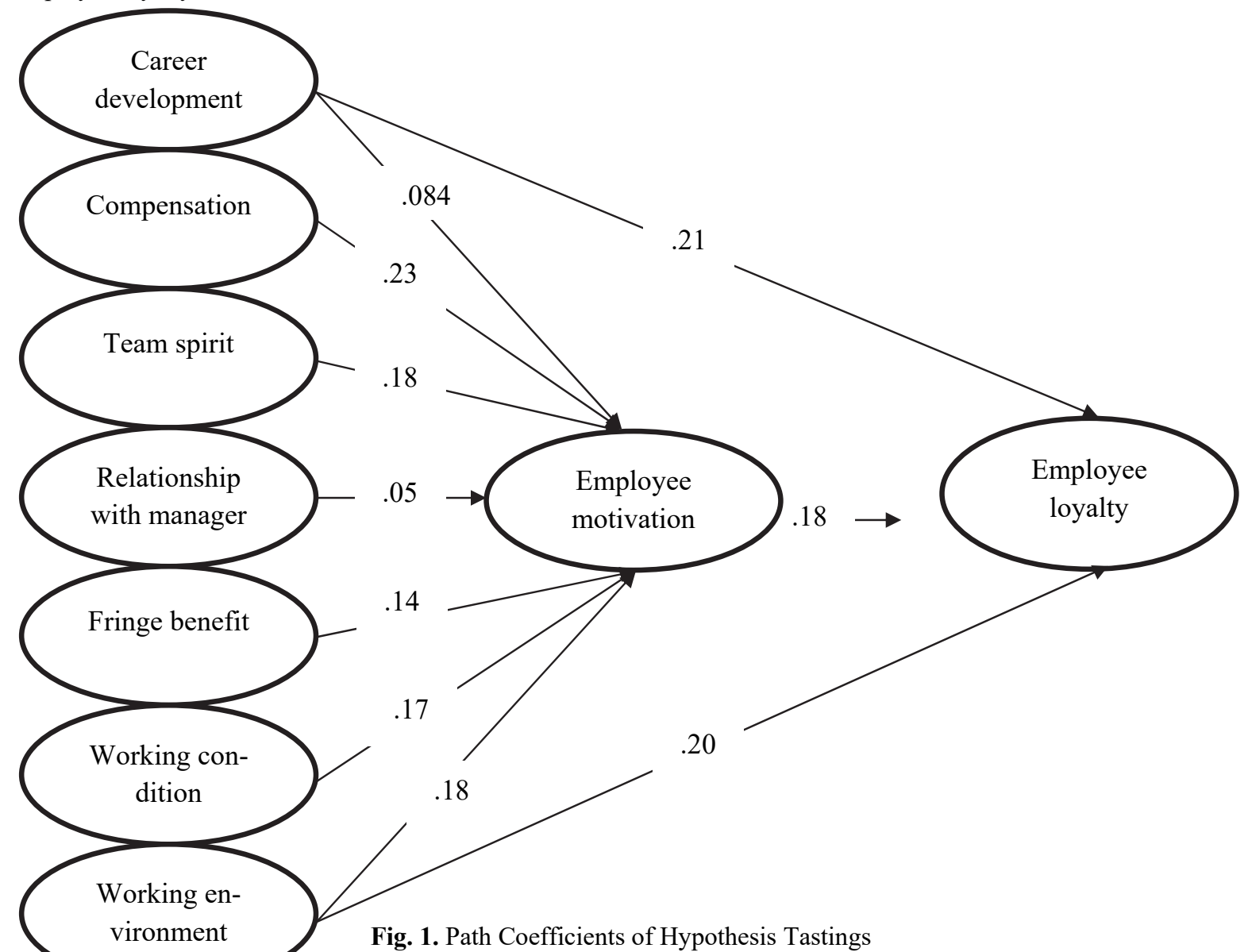

Fig. 1. Path Coefficients of Hypothesis Tastings 


\section{Discussion}

The study has clarified the direct positive relationship of team spirit, compensation, career development, relationship with manager, working environment, working condition, and fringe benefit on employee motivation. However, those factors affected not only on employee motivation but also indirectly on employee loyalty through the mediation of employee motivation. Furthermore, employee loyalty was also directly influenced by employee motivation, career development, and working environment. Thus, this research has broadened the research model for measuring impacts of human resource practices on employee loyalty and employee motivation, thereby contributing to the existing studies about organization management as well as total quality management (TQM) (Chang et al., 2010; Turkyilmaz et al., 2011; Jun et al., 2006). It can be recommended from the study that to increase employee motivation, managers in hospitality industry in Ho Chi Minh city should pay attention in developing attractive compensation and benefit policies, comfortable workplace environment, coherent teamwork culture as well as straightforward career training and development plan. Especially based on the causal effect of employee loyalty, because working environment and career development had the strongest effect on employee loyalty, hospitality leaders should take notice of building a safe and friendly working environment as well as creating more opportunities for employees to develop their knowledge and skills with specific training plan. Consequently, the higher level of employee motivation, the higher employee loyalty. In comparison with three similar researches in analyzing employee loyalty effect (Chang et al., 2010; Turkyilmaz et al., 2011; Jun et al., 2006), which were conducted in other industries (government, public sector and maquiladora industry), some differences were identified. In those studies, almost all of TQM practices acted directly and positively on employee job satisfaction, which considerably influenced employee loyalty. On the other hand, this study findings beside job satisfaction, team spirit, working environment, career development, leadership relationship and compensation also had remarkable impact on employee motivation and indirect relationship with employee loyalty through the mediation of employee motivation. In general, in addition to employee loyalty's positive consequence on service quality and organization profitability (Yee et al., 2010; Tomic et al., 2018), work motivation has either been proved to be directly positively associated with employee performance (Wibisono et al., 2018; Guterresa et al., 2019). Considered as a labor - intensive industry, hospitality industry should concentrate on employee - oriented policies to ensure the satisfaction, motivation and loyalty of employees to organization; as a result, they are able to provide exceptional quality products, services and experience for guests.

\section{Conclusion}

To sum up, the study has remarkably contributed to both theoretical and practical implication for hospitality industry in Vietnam to take a consideration in managing human resources. With a detail analysis, managers are able to prioritize in improving appropriate each factor which has impact on employee motivation and loyalty. Nevertheless, as conducted only in Ho Chi Minh City, the research might not interpret and cover enough different aspects in different regions in Vietnam. Thus, it is suggested for the future research that the more diversity in the data survey, the more convincible the research gets. More than that, it is believed that there are many other factors affecting, moderating and mediating the relationship among employee motivation, loyalty and independent human resource factors. Hence, future studies have a variety of factors and opportunities to conduct and widen understanding about human resource management in hospitality industry.

\section{References}

Al Araimi, A. (2002). Exploratory study on employees' motivation in the omani private banking sector. Journal of Public Budgeting, Accounting \& Financial Management, 14(2), 208-220.

Amabile, T. M. (1997). Motivating Creativity in Organizations: On Doing What You Love and Loving What You Do. California Management Review, 40(1), 39-58.

Arsić, M., Nikolić, D., Živković, Z., Urošević, S., \& Mihajlović, I. (2012). The effect of TQM on employee loyalty in transition economy, Serbia. Total Quality Management \& Business Excellence, 23(5-6), 719-729.

Baird, L., \& Kram, K. (1983). Career Dynamics: Managing the Superior/Subordinate Relationship. Organizational Dynamics, 11(4), 46-64.

Bettencourt, L. A., Gwinner, K., \& Meuter, M. (2001). A Comparison of Attitude, Personality, and Knowledge Predictors of Service-Oriented Organizational Citizenship Behaviors. Journal of Applied Psychology, 86(1), 29-41.

Book, L., Gatling, A., \& Kim, J. (2019). The effects of leadership satisfaction on employee engagement, loyalty, and retention in the hospitality industry. Journal of Human Resources in Hospitality \& Tourism, 18(3), 1-26.

Bui, N., \& Sid, S. (2019). The impact of human resource management practices on employee engagement and moderating role of gender and marital status: An evidence from the Vietnamese banking industry. Management Science Letters, 10(7), $1633-1648$.

CBRE. (2019). CBRE Hospitality Forum 2019 Highlights Of Vietnam Hospitality Real Estate Market. Hanoi: CBRE.

Carraher, S. M. (2011). Turnover prediction using attitudes towards benefits, pay, and pay satisfaction among employees and entrepreneurs in Estonia, Latvia, and Lithuania. Baltic Journal of Management, 6(1), 25-52.

Chang, C., Chiu, C., \& Chen, C. (2010). The effect of TQM practices on employee satisfaction and loyalty in government. Total Quality Management \& Business Excellence, 21(12), 1299-1314.

Chen, Y.-C., \& Lin, S. (2013). Modeling Internal Marketing and Employee Loyalty: A Quantitative Approach. Asian Social Science, 9(5), 99-109. 
Chew, J., \& Chan, C. (2008). Human resource practices, organizational commitment and intention to stay. International Journal of Manpower, 29(6), 503-522.

Chiu, R., Luk, V.-M., \& Tang, T.-P. (2002). Retaining and motivating employees. Personnel Review, 31(4), $402-431$.

Conger, S. (2002). Fostering a career development culture: reflections on the roles of managers, employees and supervisors. Career Development International, 7(6), 371-375.

Cooke, E. F. (1999). Control and Motivation in Sales Management through the Compensation Plan. Journal of Marketing Theory and Practice, 7(1), 80-83.

Costen, W. M., \& Salazar, J. (2011). The Impact of Training and Development on Employee Job Satisfaction, Loyalty, and Intent to Stay in the Lodging Industry. Journal of Human Resources in Hospitality \& Tourism, 10(3), 273-284.

Curtis, C. R., Upchurch, R., \& Severt, D. (2009). Employee Motivation and Organizational Commitment: A Comparison of Tipped and Nontipped Restaurant Employees. International Journal of Hospitality \& Tourism Administration, 10(3), 253269.

Dermody, M. B., Young, M., \& Taylor, S. (2004). Identifying Job Motivation Factors of Restaurant Servers. International Journal of Hospitality \& Tourism Administration, 5(3), 1-14.

F.Hayes, A. (2018). Introduction to Mediation, Moderation, and Conditiional Process Analysis. New York: The Guilford Press.

Gallie, D., Zhou, Y., Felstead, A., \& Green, F. (2012). Teamwork, Skill Development and Employee Welfare. British Journal of Industrial Relations, 50(1), 23-46.

Gandhi, S. K., Sachdeva, A., \& Gupta, A. (2018). Impact of service quality and satisfaction on employee loyalty: An empirical investigation in Indian SMEs. Management Science Letters, 8(10), 991-1014.

Gupta, N., \& Shaw, J. D. (2014). Employee compensation: The neglected area of HRM research. Human Resource Management Review, 24(1), 1-4.

Guterresa, L. F., Armanu, \& Rofiaty. (2019). The role of work motivation as a mediator on the influence of education-training and leadership style on employee performance. Management Science Letters, 10(7), 1497-1054.

Hair, J. F., Money, A., Samouel, P., \& Babin, B. (2003). Essentials of Business Research Methods. Wiley.

Hsu, S.-H., \& Wang, Y.-C. (2008). The development and empirical validation of the Employee Satisfaction Index model. Total Quality Management \& Business Excellence, 19(4), 353-366.

Hur, W.-M., Moon, T., \& Jun, J.-K. (2016). The effect of workplace incivility on service employee creativity: the mediating role of emotional exhaustion and intrinsic motivation. Journal of Services Marketing, 30(3), 302-315.

Ibrahim, M., \& Al Falasi, S. (2014). Employee loyalty and engagement in UAE public sector. Employee Relations, 36(5), 562-582.

Ineson, E. M., \& Berechet, G. (2011). Employee Loyalty in Hotels: Romanian Experiences. Journal of Human Resources in Hospitality \& Tourism, 10(2), 129-149.

Jun, M., Cai, S., \& Shin, H. (2006). TQM practice in maquiladora: Antecedents of employee satisfaction and loyalty. Journal of Operation Management, 24(6), 791-812.

Kasper, H., Muehlbacher, J., Kodydek, G., \& Zhang, L. (2012). Fringe benefits and loyalty on the Chinese labour market - a trend towards higher individual- and performance-orientation: A case study focusing on technology companies in the Shanghai region. Journal of Technology Management in China, 7(2), 164-176.

Klein, H. J., \& Kim, J. (1998). A Field Study of the Influence of Situational Constraints, Leader-Member Exchange, and Goal Commitment on Performance. The Academy of Management Journal, 41(1), 88-95.

Kroon, B., \& Freese, C. (2013). Can HR practices retain flexworkers with their agency? International Journal of Manpower, 34(8), 899-917.

Laschinger, H. K., Purdy, N., \& Almost, J. (2007). The Impact of Leader-Member Exchange Quality, Empowerment, and Core Self-evaluation on Nurse Manager's Job Satisfaction. Journing of Nursing Administration, 37(5), $221-229$.

Leather, P., Pyrgas, M., Beale, D., \& Lawrence, C. (1998). Windows in the workplace: sunlight, view and occupational stress. Environment and Behavior, 30(6), 739-762.

Lee, Y., \& Lee, J. (2018). A multilevel analysis of individual and organizational factors that influence the relationship between career development and job-performance improvement. European Journal of Training and Development, 42(3).

Li, L., \& Roloff, M. (2008). Organizational culture and compensation systems: An examination of job applicants' attraction to organizations. International Journal of Organizational Analysis, 15(3), 210-230.

Litman, L., Robinson, J., \& Rosenzweig, C. (2014). The relationship between motivation, monetary compensation, and data quality among US- and India-based workers on Mechanical Turk. Behavior Research Methods, 47(2), 519-528.

Liu, Y.-S., \& Wohlsdorf Arendt, S. (2016). Development and validation of a work motive measurement scale. International Journal of Contemporary Hospitality Management, 28(4), 700-716.

London, M. (1993). Relationships between career motivation, empowerment and support for career development. Journal of Occupational and Organizational Psychology, 66(1), 55-69.

Mak, B. L., \& Sockel, H. (2001). A confirmatory factor analysis of IS employee motivation and retention. Information \& Management, 38(5), 265-276.

Matzler, K., \& Renzl, B. (2006). The Relationship between Interpersonal Trust, Employee Satisfaction, and Employee Loyalty. Total Quality Management \& Business Excellence, 17(10), 1261-1271.

Maxwell, J. (2008). Work system design to improve the economic performance of the firm. Business Process Management Journal, 14(3), 432-446. 
McClelland, D. C. (1985). How Motives, Skills, and Values Determine What People Do. American Psychologist, 40, 812825.

Meterko, M., Mohr, D., \& Young, G. (2004). Teamwork Culture and Patient Satisfaction in Hospitals. Medical Care, 42(5), 492-498.

Milman, A. (2003). Hourly employee retention in small and medium attractions: the Central Florida example. International Journal of Hospitality Management, 22(1), 17-35.

Mudambi, R., Mudambi, S., \& Navarra, P. (2007). Global Innovation in MNCs: The Effects of Subsidiary Self-Determination and Teamwork. Journal of Product Innovation Management, 24(5), 442-455.

Parker, S., \& Wall, T. (1998). Job and Work Design: Organizing Work to Promote Well-Being and Effectiveness. London: SAGE Publications.

Pham, H. D. (2019). Impact of human resource management practices on enterprises' competitive advantages and business performance: Evidence from telecommunication industry. Management Science Letters, 10(4), 721-732.

Ramsay, H., Scholarios, D., \& Harley, B. (2000). Employees and High-Performance Work Systems:Testing inside the Black Box. British Journal of Industrial Relations, 38(4), 501-531.

Rasheed, M. I., Humayon, A., Awan, U., \& Ahmed, A. (2016). Factors affecting teachers' motivation: An HRM challenge for public sector higher educational institutions of Pakistan (HEIs). International Journal of Educational Management, $30(1), 101-114$

SHRM. (2015). Employee Job Satisfaction and Engagement - Optimizing Organizational Culture for Success. Alexandria: Society for Human Resource Management (SHRM).

SHRM. (2014). Employee Job Satisfaction and Engagement - The Road to Economic Recovery Alexandria: Society for Human Resource Management (SHRM).

Sekiguchi, T., Burton, J., \& Sablynski, C. (2008). The role of job embeddedness on employee performance: The interactive effects with leader-member exchange and organization-based self-esteem. Personnel Psychology, 61(4), 761-792.

Selvarajan, T., Singh, B., \& Solansky, S. (2018). Performance appraisal fairness, leader member exchange and motivation to improve performance: A study of US and Mexican employees. Journal of Business Research, 85, 142-154.

Singh, A., Syal, M., Grady, S., \& Korkmaz, S. (2010). Effects of Green Buildings on Employee Health and Productivity. American Journal of Public Health, 100(9), 1665-8.

Tomic, I., Tesic, Z., Kuzmanovic, B., \& Tomic, M. (2018). An empirical study of employee loyalty, service quality, cost reduction and company performance. Economic Research-Ekonomska Istraživanja, 31(1), 827-846.

Turkyilmaz, A., Akman, G., Ozkan, C., \& Pastuszak, Z. (2011). Empirical study of public sector employee loyalty and satisfaction. Industrial Management \& Data Systems, 111(5), 675-696.

VNS. (2019, September 16). Vietnam Insider. Retrieved from Vietnam Insider: https://vietnaminsider.vn/vietnams-hotel-industry-faces-challenge-in-technology/

Wang, C.-J. (2016). Does leader-member exchange enhance performance in the hospitality industry? The mediating roles of task motivation and creativity. International Journal of Contemporary Hospitality Management, 28(5), 969-987.

Watson, A. W., Taheri, B., Glasgow, S., \& O'Gorman, K. (2018). Branded restaurants employees' personal motivation, flow and commitment: the role of age, gender and length of service. International Journal of Contemporary Hospitality Management, 30(3), 1845-1862.

Wibisono, C., Nurhatisyah, \& Gustiawan, F. (2018). Work motivation and leadership on the performance of employees as predictors of organizational cul- ture in broadcasting commission of Riau islands province, Indonesia. Management Science Letters, 8(5), 247-258.

Wright, B. E., \& Davis, B. (2003). Job Satisfaction In The Public Sector: The Role of the Work Environment. American Review of Public Administration, 33(1), 70-90.

Yao, T., Qiu, Q., \& Wei, Y. (2019). Retaining hotel employees as internal customers: Effect of organizational commitment on attitudinal and behavioral loyalty of employees. International Journal of Hospitality Management, 76, 1-8.

Yee, R. W., Yeung, A., \& Edwin Cheng, T. (2010). An empirical study of employee loyalty, service quality and firm performance in the service industry. International Journal of Production Economics, 124(1), 109-120.

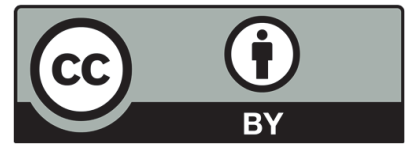

(C) 2020 by the authors; licensee Growing Science, Canada. This is an open access article distributed under the terms and conditions of the Creative Commons Attribution (CC-BY) license (http://creativecommons.org/licenses/by/4.0/). 